\title{
PENGARUH TERAPI BEKAM BASAH DALAM MENURUNKAN APOLIPROTEIN-B PADA PENDERITA HIPERKOLESTEROLEMIA
}

\author{
Wahyudi Widada $^{1}$, Teddy Ontoseno ${ }^{2}$, Bambang Purwanto ${ }^{3}$ \\ Fakultas Kesehatan Universitas Muhammadiyah Jember ${ }^{1}$ \\ Fakultas Keperawatan Universitas Airlangga Surabaya ${ }^{2,3}$ \\ Email : wahyudiwidada@unmuhjember.ac.id
}

\begin{abstract}
Hypercholesterolemia is a high level of cholesterol in the blood. Patients must take anti-cholesterol drugs for a long time, so they are at risk of experiencing side effects from the drug. Apo-B and total cholesterol are indicators of cholesterol levels in the blood. Wet cupping therapy is a method of excreting metabolic waste in the blood through the surface of the skin. The study aims to prove the effect of wet cupping therapy as a complementary therapy to decrease Apolipoprotein-B. Method: This research is Quasy experimental research using humans as research subjects. The dependent variable is Apo-B, and total cholesterol gave wet cupping treatment. Cupping is done twice, 7 points, using a G21 needle. A large sample of 32 people with hypercholesterolemia divided into treatment groups and control groups. The research subjects were selected based on sample inclusion criteria. After 12 hours of fasting and still taking simvastatin, blood was taken through $5 \mathrm{ml}$ of the brachial vein. Put into a $2 \mathrm{ml}$ purple tube containing EDTA the rest inserted in a red tube. Apo-B measurement using ELISA sandwich method, elabscience reagent, BiopharmaELISA reader tool, in units of $n g / m l$. Total cholesterol uses the enzymatic colorimetry method, diasys reagent, Biolyzerl00 spectrophotometry, in mg/dl units. Data analysis was carried out with the Wilcoxon Signed Ranks Test with a significance level of $5 \%(\alpha=0.05)$, the pre-datacompared with the post data. Results: A significant reduction in Apo-B measurements with p-value 0.000 ( $\alpha$ $<0.05)$, SD 42. Conclusion: Intervention of wet cupping therapy can reduce Apo-B levels in the blood. Further research needs to be done to measure the potential for prevention of atherosclerosis.
\end{abstract}

Keywords: wet cupping, Apo-B, cholesterol, blood

\section{PENDAHULUAN}

Bekam telah digunakan dalam kedokteran sejak zaman kuno. Bahkan Hipocrates pun menggunakan bekam pada kasus penyakit dalam (Mahdavi, et al. 2012). Lamanya sejarah bekam ini membuktikan bekam yang dilakukan secara 
benar itu aman dan efektif. Ada mispersepsi dalam memaknai bekam basah. Kedalaman jarum mengenai kulit hanya $0.05 \mathrm{~mm}$. Perlukaan dengan jarum tidak menyebabkan keluarnya darah. Darah baru keluar setelah ditarik dengan pompa berkekuatan negatif 200mmHg (Subadi, I.2014).Sebenarnya, bekam bukan tindakan membuang darah tetapi membuang sampah metabolisme yang disebut dengan causative pathological substances (El-sayed 2013). Dengan kata lain, bekam basah tidak mengurangi volume darah sirkulasi. Darah yang keluar dari perlukaan adalah "bloodlike" yang sampah metabolisme kolesterol, eritrosit yang tua, dan lain-lainl. Banyaknya darah bekam yang dilakukan secara benar tidak mengurangi haemoglobin (Mourad, et al 2016). Tujuan penelitian ingin membuktikan potensi terapi bekam basah sebagai terapi komplementer untuk menurunkan Apo-B dan kolesterol total.

Kolesterol terdapat dalam jaringan dan lipoprotein plasma dalam bentuk kolesterol bebas atau gabungan asam lemak rantai panjang sebagai ester kolesterol. Kolesterol disintesis di banyak jaringan dari asetil ko-A dan dikeluarkan dari tubuh dalam empedu sebagai garam kolesterol. Ester kolesterol merupakan bentuk penyimpanan kolesterol di hampir semua jaringan tubuh. Sumber utama kolesterol berasal dari hasil sintesis didalam tubuh sendiri yaitu kolesterol endogen serta dari makanan yang dikenal sebagai kolesterol eksogen. Asetil koA merupakan sumber semua atom karbon pada kolesterol (Murray, et al.2009).

Kolesterol tidak larut dalam cairan darah, untuk itu agar dapat dikirim ke seluruh tubuh perlu dikemas bersama protein menjadi partikel yang disebut lipoprotein, yang dapat dianggap sebagai pembawa (carrier) kolesterol dalam darah.Protein utama yang membentuk LDL adalah Apo-B (Apolipoprotein-B) (Walldius G, and Jungner I. 2004). Sebaliknya, HDL dalam operasinya ia membersihkan kelebihan kolesterol dari dinding pembuluh darah dengan mengangkutnya kembali ke hati. Protein utama yang membentuk HDL adalah Apoa (Apolipoprotein-A). Keterlibatan kolesterol HDL dalam reserve cholesterol transport merupakan suatu mekanisme melindungi endotel terhadap risiko aterosklerosis. HDL memiliki sifat antiinflamasi, antioksidan, antitrombotik. HDL juga bersifat antiaterogenik (Niasari, et al 2007).

\section{METODE PENELITIAN}

Penelitian ini merupakan penelitian Quasy experimental dengan menggunakan manusia sebagai subyek penelitian. Variabel independennya terapi bekam basah, sebanyak 7 kop didaerah punggung, pompa negatif 5 menit kemudian dilakukan perlukaan dengan jarum G21 sebanyak 15 tusukan dengan kedalaman $0.05 \mathrm{~mm}$. Variabel dependennya Apo-B dan kolesterol total. Pengukuran dilakukan dua kali, pre dan post. Besar sampel 33 orang penderita hiperkolesterolemia yang dibagi menjadi grup perlakuan dan grup kontrol. Subyek penelitian dipilih 
berdasarkan kriteria inklusi sampel, usia 45-55 tahun, tidak menderita penyakit kronis, kolesterol total $>200 \mathrm{mg}$. Setelah puasa 12 jam dan tetap mengkonsumsi obat anti kolesterol golongan statin, darah diambil melalui vena brachialis sebanyak $5 \mathrm{ml}$. Dimasukkan ke tabung ungu $2 \mathrm{ml}$ yang mengandung EDTA sisanya dimasukkan tabung merah. Pengukuran Apo-B dengan metode sandwich elisa, reagen elabscience, alat elisa reader Biopham, dalam satuan ng/ml. Penelitian dikerjakan di Laboratorium Biokimia Fakultas Kedokteran Universitas Jember.Uji etik penelitian didapat dari Komite Etik Universitas Jember pada Desember 2017

\section{HASIL DAN PEMBAHASAN}

Pengukuran data pre Apo-B pada 12 subyek penelitian diperoleh mean 2.49 SD 0.117 . Pada data post diperoleh mean 2.24 SD 0.177. Wilcoxon Signed Ranks Test diperoleh $\mathrm{p}$ value 0.005 , karena $\mathrm{p}$ value $<0.05$ maka penurunan ini bermakna.

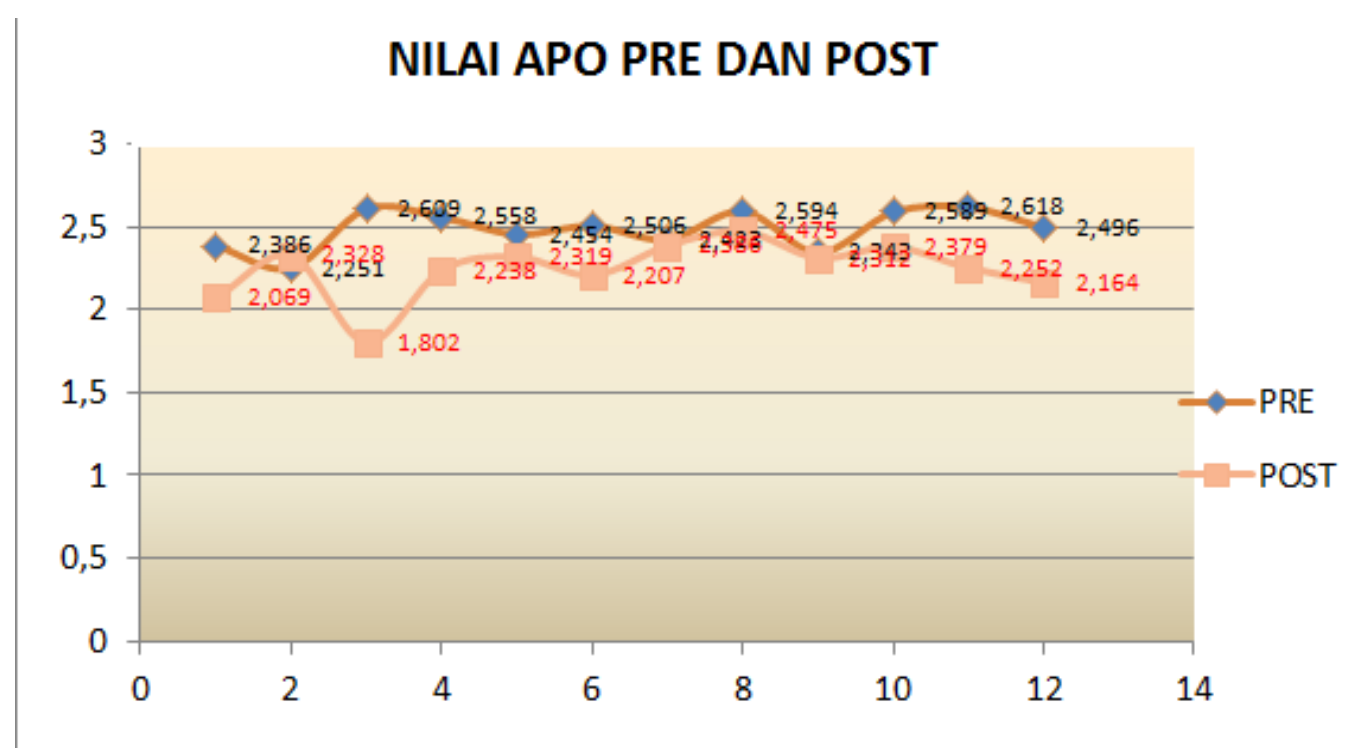


Gambar 1: Hasil pengukuran Apo-B pre dan post, $n=12$ orang (sumber: Data primer 2018)

Hal pengukuran ini sesuai dengan penelitian yang dilakukan oleh Saryono (2010), Mustafa L et al (2012), Niasari M, et al (2007) bahwa bekam dapat menurunkan kadar kolesterol. Akibat pembekaman keratinosit yang ada di kulit akan mengalami hipoksia dan menginduksi Hipoxia Inducible Factor (HIF-1 $\alpha$ ) sebagai upaya pertahanan diri (Ontoseno, 2004). HIF-1 $\alpha$ akan mengaktivasi makrofag di kulit yang selanjutnya menginduksi gen proinflamasi seperti IL-1. IL4, IL-6 dan TNF- $\alpha$ (Subadi, 2014). Interleukin-6 yang disekresikan oleh makrofag berperan merangsang respon kekebalan tubuh, misalnya setelah terjadi trauma atau kerusakan jaringan yang mengarah pada peradangan. Pelepasan IL-6 merangsang sel makrofag muda menjadi matang dan mampu melakukan fagositosis lebih efisien. IL-6 juga merangsang monosit menghasilkan sitokin inflamasi yang berperan dalam peradangan lokal maupun sistemik, akibatnya terjadi percepatan proliferasi dan diferensiasi makrofag (Ilkay, 2005).

LDL (low density lipoprotein) merupakan sumber kolesterol untuk jaringan ekstrahepatik. Bila LDL sangat berlebih, sistem ambilan LDL akan jenuh sehingga LDL yang berlebih dapat diambil oleh makrofag. Sebagian kolesterol LDL ditangkap makrofag sebelum teroksidasi. Makin banyak kadar kolesterol LDL dalam plasma, makin banyak yang akan ditangkap oleh sel makrofag. Selanjutnya makrofag akan mengalami efflux dan HDL nascent akan mendekati makrofag tersebut untuk mengambil kolesterol LDLnya. Selanjutnya HDL nascent menjadi HDL dewasa. Setelah mengambil kolesterol bebas dari sel makrofag, kolesterol bebas akan diesterifikasi menjadi kolesterol ester oleh enzim Lechitin Cholesterol Acyl Tranferase (LCAT). Jadi HDL disini berfungsi sebagai penyerap kolesterol 
LDL dari makrofag dan sebagai pembawa kolesterol LDL kembali ke hati sehingga kadar kolesterol didalam plasma menurun (Kwiterovic, et al. 2000).

Menurut El-Sayed, et al., (2013), bekam adalah prosedur bedah minor ekskretoris yang memiliki dasar medis dan ilmiah dalam membersihkan darah dan ruang interstisial dari causative pathological substanses (CPS) kolesterol sebagai produksi sampah metabolisme. Banyak hasil penelitian yang melaporkan bahwa bekam mampu menurunkan kolesterol LDL.Kolesterol HDL berfungsi sebagai penyerap kolesterol LDL dari makrofag dan sebagai pembawa kolesterol LDL kembali ke hati dengan bantuan pre $\beta$-HDL (Praningsih.2017). Pre $\beta$-HDLmemiliki peran dalam proses transport balik kolesterol (reverse cholesterol transport) yang dapat meningkatkan efflux kelebihan kolesterol dari jaringan perifer kembali ke hati untuk diekskresi melalui empedu. Percepatan migrasi makrofag juga meningkat akibat rangsangan IL-6 (Walldius, et al.200).

Perlakuan bekam basah merupakan reaksi inflamasi non infeksi yang merangsang pengeluaran mediator kimia diantaranya : IL-1, IFN- $\gamma$, IL-6, IL-8, IL18 yang akan mengaktifkan makrofag sehingga terjadi efluks kolesterol. Hal ini akan mengaktifkan LCAT (Lecitin Cholesterol Asil Transferrase) yang merubah HDL menjadi HDL3. Kolesterol berikatan dengan HDL3 untuk dibawa ke hati dan dibentuk sebagai asam empedu yang kemudian akan di ekskresikan melalui usus (Siadat, et al.2004). Melalui proses ini maka kolesterol dalam sirkulasi akan mengalami penurunan untuk diekskresi melalui usus (Kwiterovic, et al 2000).

\section{Kesimpulan}

\section{KESIMPULAN DAN SARAN}

Intervensi terapi bekam basah mempunyai potensi menurunkan kadar ApoB maupun kolesterol total dalam darah. Terapi bekam basah dapat dipertimbangkan sebagai intervensi yang dapat menurunkan kolesterol, disamping penggunaan obat anti kolesterol.

\section{Saran}

Penelitian lebih lanjut perlu dilakukan untuk mengukur potensi pencegahan terjadinya ateroskelerosis.

\section{DAFTAR PUSTAKA}

El-Sayed SM, Mahmoud HS and Nabo MMH. 2013. Medical and Scientific Bases of Wet Cupping Therapy; in Light of Modern Medicine and Prophetic Medicine. Alternative and Integrative Medicine 2: 1-16.

Ilkay Chirali, Mark Bovey, Roz Gibbs. 2005. Cupping for Patients with inflammatory Compalints: Clinical and Biochemical Outcomes 
Kwiterovich, PO Jr., MD, 2000, The metabolic pathways of high-density lipoprotein, low-density lipoprotein, and triglycerides: a current review. Am J Cardiol 2000,86:5L-10L.

Mahdavi, MRV, et al. 2012. Evaluation of the effects of traditional Cupping on the Biochemical, Hematological and Immunological Factors of Human Venous Blood. Viewed 21 Peb 2012

Mourad, SA, and Soad K. Al-Jaouni. 2016. The Effect of Wet Cupping on Blood Haemoglobin Level. Alternative Integration Medition 2016, 5:2

Murray Robert K., Granner Daryl K., Rodwell Victor W., 2009. Biokimia Harper, Jakarta: EGC

Mustafa L., Dawood M. Rukzan, Al-Sabaawy M. Osama, 2012. Effect of Wet Cupping on Serum Lipids Profile Level of Hyperlipidemia Patients and Correlation with some Meal Ions. [online] Available at : http://www.iasj.net/iasj?func=fultext\&ald=60009.pdf

Niasari M, Kossari F, Ahmadi A, 2007. The Effect of Wet Cuping on Serum Lipid Concentrations of Clinically Healthy. The Journal of Alternative and Complementary Medicine. Volume 13, Number 1, 2007, pp. 79-82

Praningsih, S.2017. Efektifitas Spritual Cupping Care dibandingkan Cupping Care dalam menurunkan Kolesterol LDL. Thesis. Repository Unair

Siadat SO Ranaei., Kheirandish h., Niasari., Adibi Z., Agin K., Tashnizi M B. 2004. The effect of cupping (hejamat) on blood biochemical and immunological parameters. Iranian Journal of Pharmaceutical Research: Supplement 2: $31-32$

Subadi, I. 2014. Mekanisme penurunan nyeri inflamasi terapi bekam kering dan bekam basah. Disertasi. Universitas Airlangga. Tidak dipublikasikan

Saryono, 2010. Penurunan kadar kolesterol total pada pasien hipertensi yang mendapat terapi bekam di klinik An-Nahl. Purwokerto., 5(2), pp.66-73.

Walldius G, and Jungner I. 2004. Apolipoprotein B and apolipoprotein A-I: risk indicators of coronary heart disease and targets for lipid-modifying therapy. Journal of Internal Medicine 2004; 255: 188-205. 